\title{
PROMOTING STUDENTS' SPEAKING ABILITY THROUGH ROLE PLAY WITHIN DICOURSE BASED APPROACH
}

\author{
Lilik Handayani, S.S.
}

\begin{abstract}
In teaching English for engineering students, the emphasis goes to understanding the technical terms within reading scientific texts, writing technical report, and speaking on certain topics relevant to the major specialization. Students of Shipbuilding Institute of Polytechnic Surabaya (SHIPS) are demanded to be able to communicate actively either in oral or written English particularly after graduation when they work in offshore, mining and shipyard industries.

Therefore, this study is aimed to promote students' speaking ability through role play within discourse based approach. Role play is selected to develop students' knowledge about why, how and when to communicate based on the real-life context and their specialized background. Students are encouraged to act out the roles with a partner in speaking tasks. A continuum of spoken texts in English are provided to explore students macro and micro-level discourse awareness. This paper elaborates the stages of designing speaking tasks focusing on role play.
\end{abstract}

Keywords: Role play, Discourse based approach, ESP

In the field of English Learning and Teaching (ELT), speaking has always been considered as the most paramount skill to be mastered for several reasons. Since approaches and methods for teaching speaking have long been major focuses of language teaching researches and conferences. Moreover, the outcome of effective language learning is usually measured through learners' speaking ability. They are supposed as succcesful English learners, when they are able to speak in English fluently and accurately.

Nowadays, the needs of English mastery particularly speaking or communication skills can't be denied any longer. The preliminary study has been conducted through interview with the alumni and graduates from vocational education like Shipbuilding Institute of Polytechnic Surabaya (SHIP). Beside achieving 500 TOEIC score as graduation requirement, it is necessary for them to have communicative competence to build their future professional career in offshore, mining and shipyard industries.

This study aims to design speaking tasks and activities by using role play and incorporating discourse based approach. Thus, this study is intended to promote 
students' speaking ability based on the implementation of role play which represents the real-life context and their specialized background.

\section{The Rationale for Using Role Play within Discourse Based Approach}

A role playing game is an interactive activity or language games in which the participant or students of a language course assume the roles of some imaginary characters and as a team create a story based on situation and enact the play in front of audience. The objective of role play is to help students practice certain language functions and learn speaking skills.

According to Krish (2001) role play encourages peer learning and sharing of responsibility between teacher and the learners in the learning process. Students are encouraged to involve and participate actively in the learning speaking tasks. These are some features of a good role-play: (1) It is based on a familiar situation and relevant to real world context so students can speak naturally, (2) The group of characters does not exceed 2-3 members and it takes 4-7 minutes, and (3) It fosters students' critical thinking and creativity, and (4) It gives extensive speaking practice to all the participants (Pravan 2008).

\section{The Key Principles of Incorporating Discourse in Language Teaching}

Before integrating and incorporating discourse based approach in speaking classroom, Hymes's SPEAKING grid should be taken into account in understanding the different component of communication. That grid is an abbreviation for Setting scene, Participant, Ends, Act sequence, Key, Instrumentalities, Norm of interaction and interpretation, and Genre. Those eight elements of Speaking grid provides a necessary reminder of the contextual dimensions that determine our language use. The broader notion of the communicative competence proposed by Hymes (1972) should also be supported by sociolinguistic competence, discourse competence and strategic competence as well. Therefore, students are taught not only linguistic form and expression, but rather on improving and implementing their knowledge on understanding the context why, how and when to communicate by using an appropriate utterances. 
The main issues of teaching English for specific purposes are quite the same with English as a foreign language in Indonesian context, since the typical classroom environment is dealling with some students who are highly motivated, semi-motivated or unmotivated in speaking English. Teachers of English may experience the same situation in which the students are reluctant to speak. There are of course many factors causing the problem. Students feel that they lack of confidence to speak as the result of not knowing what to say. Some others might state that they are lack of vocabularies especially dealing with technical terms of shipbuilding and maritime studies to say in a conversation or dialogue. Sometimes even motivated students decide to be passive because the activities do not make them enthusiastic.

In spite of getting frustrated to develop students' speaking ability, English teacher should be creative in designing communicative tasks and providing adequate opportunity for students to involve in communicative activities as well as motivating them to practice speaking in a pair or group. Thus, the focus of this study is directed to design and implement speaking tasks using role play to scaffold students' English proficiency.

There are some stages should be taken into account before designing a discourse-based approach syllabus: (i) the segmentation of discourse, (ii) sequencing, (iii) selection and presentation of instances of language use.

\section{a. The segmentation of discourse}

The discourse should be selected for its mode (written vs. spoken or dialogic vs. monologic), genre (reporting,narrating, persuading, arguing, describing,instructing, etc.), and strategies. Mc Carthy and Carter (1994) explain further about the types of strategies that should be taken into account in immersing discourse, they are:

1. Genre-related strategies: most frequent media, modes and genres; patterns of interaction(narrative, problem-solution).

2. Coherence-related strategies: topic management, turn-taking, cohesion.

3. Politeness strategies: face, forms of address, reciprocity. 
4. Planning strategies: anticipatory strategies (enumeration, cataphoric use of articles and pronouns), sequences of tense, aspect and voice, appropriate degree of creativity and risk-taking.

5. Convergence strategies: informational and cognitive convergence (theme, mood and modality), affective convergence (solidarity routines, agreement disagreement), shared cultural knowledge.

6. Repair strategies: risks of communicational problems and cultural misunderstandings, self-repair, cooperative peer repair.

\section{b. Sequencing}

Sequencing refers to the way / order of presentation, including top-down approach and bottom-up approach. Cots (1996) defines top-down process as "..moving from the highest units of analysis to the lowest." It is starting with background knowledge and expectations about the purposed contents of the message and the structure of the text (the sender, the intended receiver, the purpose, the genre) and looking for confirmation of these at the lower levels. Meanwhile, bottomup approach ".. begins with the smallest units of language (i.e. sounds, letters) and continues through a series of inclusive levels up to the levels of the text or discourse." The order of these levels (from the lowest to the highest) are defined by Cook (1989): sounds and letters, grammar and lexis, cohesion, conversational mechanisms, discourse function, discourse structure, discourse type, shared knowledge, and social relationships.

\section{c. Selection and Presentation of language sample}

In selecting and presenting the real language sample (discourse), there are five principles to consider (Mc Carthy \& Carter), they are:

1. The contrastive principle. The selected discourse should be able to provide comparation or contrast with different situation/ texts between in the foreign language and in the learner's first language.

2. The continuum principle: The selected discourse should not separate but show continuum role of its participants. 
3. The inferencing principle: The taken sample should carry a cultural load in order to make sense of it. Thus, inferring meaning strategies should be also taught.

4. Familiar to unfamiliar principle: the discourse-based tasks should scafffold from simple and familiar into the more complex, elaborated and decontextualized.

5. The critical principle: the language sample could be as a means of creating ideology beyond the language itself, but also to social issues for instance.

\section{The Implementation of Discourse Based Approach in Teaching Speaking}

Integrating discourse based approach in teaching speaking can't be separated from introducing learners to some of the features of 'real-life' discourse, such as generic structure, associated grammatical choices, and the role of pronunciation in creating meaning. Students are then exposed to the discourse and authentic spoken text, so they are able to notice and analyze authentic and appropriate usage of language. Discourse based activities enable students to extend and prepare their communicative repertoire and prepare them more effectively for communication in the target language outside the classroom.

\section{Designing Discourse Based Tasks in Speaking}

In designing speaking activities or instructional materials for second language or foreign-language teaching, it is also necessary to recognize the very different functions speaking performs in daily communication and the different purposes for which our students need speaking skills (Richards, 2008).

The following speaking tasks are designed for the freshmen or the first semester students of Shipbuilding Institute of Polytechnic Surabaya in promoting their speaking ability through role play: 
Table 1. The Design of Speaking Tasks

\begin{tabular}{ll}
\hline Level & The first semester students of SHIPS \\
\hline Skill & Speaking \\
\hline Genre & A dialogue \\
\hline Text Type & Descriptive text \\
\hline Standard of & $\begin{array}{l}\text { Expressing meaning in short functional spoken text and } \\
\text { dialogue in the form of descriptive in a daily life context. }\end{array}$ \\
\hline Competence & $\begin{array}{l}\text { Expressing meaning and rhetoric structure in a dialogue } \\
\text { by using accurate, fluent, and acceptable spoken } \\
\text { expression in the descriptive spoken discourse }\end{array}$ \\
& $\begin{array}{l}\text { Students are able to make sentences in imperative tense } \\
\text { Students are able to give warnings and discuss about } \\
\text { maritime safety }\end{array}$ \\
\hline Sim/Goal & $\begin{array}{l}\text { IMO safety regulation } \\
\text { Teacher made worksheets }\end{array}$ \\
\hline Teaching Materials & Students' worksheet \\
\hline
\end{tabular}

Procedures of employing the speaking tasks within discourse based approach is started from Pre- Speaking:

1. Opening the lesson

2. Brain storming to activate students' schemata (by showing some pictures of safety signs or symbols used on the sea)

3. Playing the video presentation of IMO Safety Regulation Asking the students to fill out their worksheet while watching the presentation (the worskheet contains some points to find, like: "what should shipmen prepare before launching the ship?" what should they do when there is technical trouble with the engine? How to evacuate victims when the disaster occurs? Etc.

4. Providing the context and a role play task based on IMO safety regulation and the technical terms or particular vocabularies dealing with maritime safety.

5. Make a conversation and act it out as safety engineer and quality control staff at Asian Cruise when the accident occurs.

6. Students are given 30 minutes to prepare their dialogue or role play between safety engineer and quality control staff.

While-speaking activities

1. delivering checklist and scoring scale to each students 
2. asking the students to fill out the checklist and scoring scale when their friends are presenting in front of the class.

3. recording the students' dialogue and conversationn (to be used as the assessment later)

4. giving comments in the comment sheet

Post-Speaking activities

1. leading a voting for the best speakers of the day

2. giving some tips on carrying out cooperative conversation

\section{Discussion}

Talking about the IMO safety regulations. The sequence of this task is topdown approach, in which the students are exposed to the complexityof the discourse before analyzing the parts or the elements of the talk. The selection and presentation of the discourse follows the critical principle to create ideology for social issues. This discourse-based task involves a conference talk by a native English speaker at the normal speed. $100 \%$ comprehension of this talk is impossible to my students, but meaning inferencing could be possible. When they know what information they need to find, they will focus on this task instead of listening every single word. For this reason, students are given a worksheet where they will find out some required information about the speech. The list of the questions are chosen carefully as such so that it could cover the overall meaning of the talk.

As this task is a productive one, the preparation stage spend the most of the time. Activity 2 to 3 are aimed at giving input to the students about lecture of IMO safety regulation. Activity 6 to 8 are purposed to dig up the students' own knowledge about the topic, could be from their own experience, observation, or their ideas. This draft writing could be the hardest part for the students as they need to cover some aspects at the same time: the content of their dialogue, the way they communicate, and the audience expectation.

The while-speaking activities provide opportunity for peer-assessment towards the students' talk. This could be a bias but informative activity to do as the scoring scale informs the speakers about their strength and weakness of the dialogue 
and it will be a constructive comment for the future speaking tasks. This whilespeaking activity is also a medium for negotiating meaning to the audience. The speakers can use gestures, mime, facial expressions, visual aids to help them communicating their ideas. The post-speaking activities are designed to appreciate the effort of the students. There are two best speakers: students' choice and teacher's choice.

At a macro level of discourse, students are encouraged to: (1) identify whether text is primarily transactional or interactional, (2) highlight the typical discourse which unfold in spoken interaction, and (3) identify situation where speakers may have unequal power relation and how language is used to confirm or context theses rules. This is important to clarify reasons for crosscultural misscommunication where different expectations may be at play. Whereas at a micro level, learners are thaught to understand the exchange structure showing how speakers position themselves to hold the floor and the strategies they use to do this (challenges, disprefered responses, and clarification check). In turn taking, students are taught to highlight what kinds of turns are likely to go together and how speaker can take up or modify different kinds of turn. Meanwhile, conversational moves are enabling learners to practice expressions realizing conversational opening, closing, evaluative followup, back chanelling.

Teacher should explain that the function of speaking task in here focuses on what is said or done regarding the style of speaking can be quite formal among colleagues on the ship and speaking task refers to talk as transaction. Thus, the message and making oneself understood clearly and accurately is the central focus, rather than the participants and how they interact socially with each other. The role play in this speaking task involves situations where the focus is on giving and receiving information and where the participants focus primarily on what is said or achieved (i.e. asking and informing about safety rules dealing with the process of launching the ship, the procedure to fix the engine and the procedure of victim evacuation when the disaster happens. According to Burns (1998), in the first type of talk as transaction, accuracy may not be a priority as long as information is successfully communicated or understood. 


\section{Conclusion}

The main goal for every language teachers is to facilitate the learners' into a communicative language users. Using role play in speaking task functioning talk as transaction is expected to help our learners to become efficient and effective participants in real communicative situations and that this involves more than the knowledge and skills necessary to manipulate the structures of a language. Then teachers must inevitably appeal to a theory of language use that attempts to integrate its social, cognitive and linguistic strands. Therefore, integrating discourse into language teaching is a powerful tool to expand the learners' real language input and widen their knowledge about meta-language aspects.

Learners should be taught how to perform role play as a form of talk as transaction. Regarding Richards' review (2008) that talk as transaction is more easily planned since current communicative materials are a rich resource of group activities, information-gap activities, and role plays that can provide a source for practicing how to use talk for sharing and obtaining information, as well as for carrying out real-world transactions. These activities include ranking, values clarification, brainstorming, and simulations.

The implications for teaching speaking and integrating the discourse based approach will be on developing students' awareness of the different discourse features by applying consciousness-raising approach. Thus, students are not only exposed to the 'recipe' type models without comprehending the discourse features at the macro or micro level (Burns and Joyce, 1997). Then, teachers should recognize issues need to be addressed in planning speaking activities for an English class. The first is to determine what kinds of speaking skills the class will focus on. Is it all three of the genres described in the preceding section, or will some receive greater attention than others? Informal needs analysis is the starting point here. Procedures for determining needs include observation of learners carrying out different kinds of communicative tasks, questionnaires, interviews, and diagnostic testing (e.g., Tsang and Wong 2002). The second issue is to identifying teaching strategies to "teach" (i.e., provide opportunities for learners to acquire) each kind of talk. 


\section{References}

Burns, Anne (1998). Teaching speaking. Annual Review of Applied Linguistics $18: 102-123$

Burns, Anne and Joyce, H. Focus on Speaking. (Sidney: National Centre for English Language Teaching and Research), 1997.

Cook, G., Discourse, (Oxford: Oxford University Press), 1989

Cots, J.M., Bringing Discourse Analysis into the Language Classroom, Links \& Letters 3, 1996 p. 77-101

Hymes, D., An Intoduction to Applied Linguistic . Pride, J. and Holrnes, J. (eds.), Sociolinguistics (Hardmonsworth, England: Penguin)

McCarthy, M., Carter, R. Language as Discourses: Perspectives for Language Teachers. (Cambridge: Cambridge University Press), 1994.

Richards, Jack C, Teaching Listening and Speaking from Theory to Practice. (New York: Cambridge University Press), 2008

Schmitt, M, \& Carter, R, (eds.) Language as discourse: Perspectives for language teaching, (London and New York: Longrnan), 1994

Schmitt, N. An Introduction to Applied Linguistics. Hodder Arnold 2002.

Tsang, W.K., and M.Wong, Conversational English: an interactive, collaborative and reflective approach. In Jack C. Richards and Willy Renandya (eds.), Methodology in Language Teaching. (New York: Cambridge University Press), 2002. 